\title{
Lumen
}

Selected Proceedings from the Canadian Society for Eighteenth-Century Studies

\section{The "candour, which can feel for a foe": Romanticizing the Jacobites in the Mid-Eighteenth Century}

\section{Pam Perkins}

Volume 31, 2012

URI : https://id.erudit.org/iderudit/1013072ar

DOI : https://doi.org/10.7202/1013072ar

Aller au sommaire du numéro

Éditeur(s)

Canadian Society for Eighteenth-Century Studies / Société canadienne d'étude du dix-huitième siècle

ISSN

1209-3696 (imprimé)

1927-8284 (numérique)

Découvrir la revue

Citer cet article

Perkins, P. (2012). The "candour, which can feel for a foe": Romanticizing the Jacobites in the Mid-Eighteenth Century. Lumen, 31, 131-143.

https://doi.org/10.7202/1013072ar

Copyright (c) Canadian Society for Eighteenth-Century Studies / Sociéte canadienne d'étude du dix-huitième siècle, 2012
Ce document est protégé par la loi sur le droit d'auteur. L'utilisation des services d'Érudit (y compris la reproduction) est assujettie à sa politique d'utilisation que vous pouvez consulter en ligne.

https://apropos.erudit.org/fr/usagers/politique-dutilisation/ 


\title{
The "candour, which can feel for a foe": Romanticizing the Jacobites in the Mid-Eighteenth Century
}

\author{
PAM PERKINS
}

University of Manitoba

Queen Victoria and Eliza Haywood are not often mentioned in the same breath, probably for good reason. Yet however dissimilar in almost every respect, they are linked in having been credited with what might appear, on the face of things, to be an improbable taste for romantic narratives about the fate of Charles Edward Stuart. Queen Victoria's sentimental Jacobitism has attracted amused commentary almost from the moment of her death; an early twentieth-century biographer of the Scottish songwriter Lady John Scott, for example, demurely compared Scott to the Queen in the strength of her "Jacobite leanings." Of course, Scottish Jacobitism had been thoroughly romanticized long before Victoria was born. As early as the mid-178os, when Boswell published his account of Flora MacDonald and the other surviving Jacobites whom he met during his tour of the Hebrides, melancholic nostalgia, rather than political anxiety or triumphalism, had started to become the dominant tone for mainstream literary treatments of Jacobitism. Within a generation, the figure of the tragically misguided but appealing Jacobite had become a fixture in popular culture, thanks in large part to the phenomenon of the Waverley novels, and was to remain so for much of the nineteenth century. Yet matters were rather different when Eliza Haywood was briefly imprisoned early in 1750 for distributing a pamphlet sympathetic to Prince

1. Margaret Warrender, ed., Songs and Verses by Lady John Scott (Edinburgh: D. Douglas, 1904), lii-liii. 
Charles. While it is very clear now that Jacobitism was dead as a political threat to Hanoverian Britain by the autumn of 1746 , that would not have been as obvious to the London authorities just a little over three years later; given the date, any pamphleteering that could be construed as pro-Stuart would have an inescapably political edge. Even so, the pamphlet that landed Haywood in prison would probably not satisfy historians looking for traces of Jacobite political activity in immediately post-Culloden Britain, as it subordinates politics to romance and makes the Charles who appears in it far more implausibly heroic than Scott's version in Waverley. Yet the pamphlet is far from unique in that respect, as there is an array of material from the later 1740 s and early 1750 s in which one sees representations of Charles Stuart that would fit comfortably into the sentimental historical fiction that delighted Victoria and the Victorians. Little read today, these ephemeral documents suggest not just the speed with which Jacobitism was transformed, in the popular imagination, from political threat to sentimental romance but also, and rather more interestingly, the complicated ways in which the mid-eighteenth-century debates about Jacobitism were implicated in shaping idealized concepts of Britishness in the literature of the day.

The idea that by the end of the eighteenth century a number of mainly Scottish writers had started to absorb Jacobitism into Hanoverian cultural myth is familiar. More than two decades ago, Peter Womack demonstrated that Boswell's sympathetic narratives of Jacobite survivors are central to his own self-construction as an exemplar of modern, and loyally Hanoverian, virtue. ${ }^{2}$ What these pamphlets show is that this is a process that began at least a generation before Boswell was writing; in addition, while many of the pamphlets are anonymous, most were printed in London, which suggests that it wasn't strictly a Scottish phenomenon. Indeed, more or less melodramatic recreations of Charles Stuart's escape started to appear in the English press almost as soon as the prince got on the boat to France, and while almost all of them, no matter how extravagant their details, insisted vigorously upon their meticulously researched accuracy, their appeal was not simply to those interested in gathering the latest news.

2. See Peter Womack, Improvement and Romance (Basingstoke: Macmillan, 1989). 
These are works that used popular literary idioms in order to reimagine dramatic current events and to re-interpret a controversial and, up till a very short time before, much feared figure. In doing so, they create versions of Charles Stuart and his supporters who belong more in the world of romance and sentiment than that of politics and war, and while this shift into romance doesn't necessarily depoliticize the Jacobites, it does suggest, implicitly or explicitly, that that sentimental sympathy is both somehow beyond politics and, at the same time, a key element drawing together virtuous British readers of all political stripes.

What is most striking about the pamphlets about Charles Stuart that appeared in the five years or so after the defeat at Culloden is how few are uniformly negative in their presentation of him. Unsurprisingly, it is not that difficult to find unflattering representations of Charles Stuart before that; to take just one example, a 1745 pamphlet that claims to be "A Genuine Intercepted Letter" from one Patrick Graham, Charles Stuart's confessor, is in fact a work of sustained irony in which Graham's supposed praise of the prince touches on just about every imaginable Protestant anxiety about Stuart tyranny and Catholic deviousness and intolerance. (Graham's only criticism of Charles arises from his worry that the prince's tendency to speak "the Language of his Heart" when the subject of Protestantism comes up makes him insufficiently skilled in the valuable art of lying convincingly to heretics. ${ }^{3}$ ) If one judges by the impact of this "letter," English readers seemed to be quite happy to believe, in the lead-up to Culloden, that Charles was an uncompromising religious bigot and a would-be tyrant. The editor of what is perhaps the best-known of the anti-Jacobite pamphlets, Henry Fielding's History of the Present Rebellion in Scotland, calls the Graham pamphlet "one of the first propaganda successes of the rebellion," despite the easily-established facts that Charles Stuart was not only not travelling with a priest named Patrick Graham, but that no such person appears to have existed. Even as sophisticated a reader as Henry Fielding at least affected to believe that the letter was genuine, as he chose to feature Graham in his account

3. A Genuine Intercepted Letter, from Patrick Graham... to Father Benedick Yorke (London: M. Cooper, [1745]), 4.

4. W. B. Coley, ed., The True Patriot and Related Writings (Middletown, Conn.: Wesleyan UP, 1987), xlix. 
of the Jacobite uprising, even while assuring his readers that he had taken "the utmost Pains" to "ensure the Truth of the Facts related."

Such pro-government propaganda of course has its counterpoint in straightforwardly Jacobite celebrations of Charles, appearing both before and after 1746 . As late as 1750 , for example, one finds an anonymous pamphleteer using Henry Goring (who, unlike Graham, was an actual member of the prince's staff) in a somewhat belated argument for Jacobite political legitimacy. Written as a dialogue between Goring and an anonymous Protestant aristocrat who encounters him in Avignon, this pamphlet turns into a political catechism, in which Goring's responses to Hanoverian doubts about Charles' character and his Catholicism present Charles as the epitome of enlightened liberal tolerance - so much so that the newly ex-Whig traveller is moved, in the space of just forty duodecimo pages, to exclaim joyfully to "Goring" that

You have [...] undeceived me in those prejudiced Notions of the $S-t$ Family, which I have been educated in from my Cradle; and for the future, not all the Promises, Threatnings, or even Force itself, shall compel me to do a Thing in the least detrimental to their Interest, but in the mean Time should be glad, as a Proselyte, to pay my Obedience to a $\mathrm{P}$ - who justly deserves the Admiration of the World. ${ }^{6}$

Such unsubtle politicking was relatively rare, however, even in pamphlets that were laudatory about Charles. Indeed, the fact that the title-page of the Goring pamphlet omits not just the author's name, but also the printer's and the place of publication might hint that the anonymous printer saw it as an unusually dangerous political provocation. What was much more usual were pamphlets that turned Charles into a figure of romance and that, in doing so, blurred the sort of explicit propagandizing in favour of a Stuart restoration that one finds in the Goring dialogue.

The pamphlet that got Eliza Haywood in trouble is a case in point. ${ }^{7}$ Admittedly, most Haywood scholars, when they touch at all on this

5. Coley, 35 .

6. A Conference Lately Held Betwixt $H-G-g$, Esq; and a Certain E-h L-d at $A-n, 1750$.

7. Haywood denied authorship and insisted that she had done nothing more than distribute it; see Catherine Ingrassia, "Additional Information about Eliza Haywood's 1749 Arrest for Seditious Libel," Notes and Queries 44.2 (1997): 202. Patrick Spedding, however, includes the pamphlet in his list of Haywood publications (A Bibliography 
"pamphlet-letter in praise of the Young Pretender," have read it as more or less surprising evidence of Haywood's otherwise unsuspected Jacobite politics. Even Catherine Ingrassia, in a subtle and convincing reading that demonstrates that Haywood might have been motivated as much by profit as by politics and that she was attempting to "capitalize $[. .$.$] on a popular demand for political writings," sees the work as$ an attempted demonstration of Charles' "political viability." "The main exception to this consensus is Earla A. Wilputte, who has offered by far the most detailed analysis of the pamphlet to date and who disagrees strongly with Ingrassia and almost every other commentator in her assessment of its political implications. She argues, first, that there is a deep, pervasive irony in Haywood's treatment of Charles and, second, that the pamphlet's narrative style "reflects upon both Jacobite and Hanoverian discourse" and, in doing so, undercuts the political myth-making on both sides of the debate..$^{10}$ Yet even if Wilputte's careful reading of the pamphlet exposes nuanced political satire, it is still important not to overlook the fact that Haywood's surface plot remains strikingly and cheerfully in the genre of romantic adventure. Like the anonymous 1750 pamphlet discussed above, its defence of Charles is presented in the voice of Henry Goring, but Haywood's Goring presents Charles not just as a model of monarchical virtue, but as something of an eighteenth-century superman. While he opens the narrative with a polished and impassioned - if impromptu - lecture on the responsibilities of kings to their subjects, Haywood's Charles speedily turns his attention to more conventionally entertaining matters, such as rescuing a beautiful, scantily-clad teenager from a burning building - and then nobly resisting her attempts to seduce him - and all but single-handedly fighting off a would-be assassin. (The figure of the amorous virgin, overcome by sexual longing for an irresistibly charming man, links this pamphlet with more familiar work by Haywood, although as Ingrassia dryly notes, Charles' restraint is "atypical for a

of Eliza Haywood [London: Pickering and Chatto, 2004]), while both Ingrassia and Earla A. Wilputte (see below) at least tentatively accept the attribution.

8. Kirsten T. Saxton and Rebecca P. Bocchiccio, eds., The Passionate Fictions of Eliza Haywood: Essays on her Life and Work (Lexington: UP Kentucky, 2000), 3.

9. Catherine Ingrassia, Authorship, Commerce and Gender in Early EighteenthCentury England: A Culture of Paper Credit, (Cambridge UP,) 116, 118.

10. Earla A. Wilputte, "Parody in Eliza Haywood's A Letter from H- G-g, Esq," Eighteenth-Century Fiction 17.2 (2005): 223. 
Haywood hero." "l) "Goring," meanwhile, is left with little to do but proclaim his breathless admiration for Charles and to report on the "Rapture" with which all who speak with the Prince greet every word he says. ${ }^{12}$

Wilputte's reading of this pamphlet in the wider context of Haywood's career does offer very strong grounds for seeing it as a subtle parody of political language, all this melodrama notwithstanding, but in shifting the context from Haywood's work to that of other, more or less contemporary, ephemera on Charles and the Jacobites, matters change a little. Even granting the unusually sophisticated literary and political subtleties implicit in Haywood's over-the-top presentation of Charles, one is, in the latter case, still left with the challenge of explaining the sheer number of more or less similarly sympathetic accounts of him that appeared in the four or five years after Culloden, many of them supposedly the work of good English Hanoverians. The self-proclaimed Hanoverian author of a pamphlet called The Wanderer, for example, complains that well before sitting down, in 1747 , to write his own narrative of Charles, he had been exhausted by his attempt to keep up with the "almost, daily accounts of the young adventurer's travels and hardships, after the battle of Culloden."13 Even so, he explains that he felt obliged to add to that pile of material after a careful examination of the supposedly hostile misrepresentations of Charles in the 1746 pamphlet Ascanius (again published anonymously, but Ralph Griffiths was arrested and questioned about it). In fact, Ascanius is far from being as harsh on Charles Stuart as the author of The Wanderer implies, but more to the point here are The Wanderer's comments on Griffiths' arrest, as the author scoffs at the idea that Ascanius could be politically dangerous. The "turgid stile," the writer says, in fact led him to assume on first reading that it was "the Performance of a certain female Author" - perhaps a hint that Haywood's name had already been associated with pamphlets about Charles Stuart - but he quickly decided otherwise when he "found it contained no Smutt."14 Given

11. Ingrassia, 118 .

12. Eliza Haywood, A Letter from H G-g, Esq.... To a Particular Friend (London, 1750), 15 .

13. The Wanderer: Or, Surprizing Escape: A Narrative Founded on True Facts (London: Jacob Robinson, 1746), 1.

14. The Wanderer, 2. 
what he insists is Ascanius' incompetence as both literature and propaganda, he concludes that "the bookseller" must have "informed against himself, that he might be taken up, as all the public papers would, by that method, advertise his work for nothing; which, by raising people's curiosity, might carry off another edition." 15

Even if one is doubtful that Ralph Griffiths engineered his own arrest for seditious treason in order to make a place for his work in an over-crowded market, this passage is intriguing in its implication that money, more than politics, was driving the competitive pamphleteering about Charles Stuart. The two factors can't be entirely separated, of course: huge public interest in the dramatic political implications of the rebellion was part of what made pamphlets about it so saleable. Yet in placing these early, sympathetic narratives of Charles Stuart even partially in the world of literary commercialism (as opposed to that of straightforward political partisanship), one is left with the intriguing question of why these writers appeared to take for granted that the English pamphlet-buying public would be more inclined to buy sympathetic accounts of a man who had, after all, invaded their country only a short time before.

In some cases, admittedly, that sympathy is expressed in a manner that directly and explicitly makes case for Hanoverian rule, making the appeal of the narratives to a whiggish English readership fairly selfexplanatory. In one particularly ingenious 1746 pamphlet, we are presented with what is supposedly a letter from Charles to his younger brother, in which he confesses that, while hiding out in the Highlands, he has spent his time reading the pro-government pamphlets that for some reason happened to be at hand. The result, Charles explains, is that he is now a supporter of the Hanoverian establishment. "What am I," Charles is made to ask his brother in one letter,

that I should attempt to deprive a free People of the Happiness of living under such a Government as they are satisfied with? That Nature gave them the Liberty of chusing for themselves, they have proved by demonstrative Arguments, and that this Liberty is secured by their Laws is known to all the World. ${ }^{16}$

15. The Wanderer, 3.

16. Some Account of the Melancholy Situation of the Young Pretender in Scotland (London: H. Carpenter [1746]), 22. 
In a neat bit of political fantasy, the virtuous devotion to liberty and to the welfare of the British people that the two "Goring" pamphlets insist are Charles' guiding principles here become a mode of underscoring the supposed glories of Hanoverian rule.

In part, what makes this creation of a tragically misled, as opposed to melodramatically evil, version of Charles Stuart so potentially compelling to a non-Jacobite readership is that this sentimentalized picture of the prince lamenting the damage caused by his "youthful Heats and Thoughtlessness" and praying that his own sufferings might atone for the havoc wreaked by his rebellion co-opts, rather than counters, Jacobite propaganda. ${ }^{17}$ Jacobite narratives had, from the beginning, played up the romance of a dashing young prince first trying to reclaim his family's lost throne and then casting himself on the loyalty and generosity of his most impoverished supporters. Generosity was, of course, one of the virtues most calculated to thrill the eighteenthcentury heart and while at least some of Hanoverian responses involved resolute debunking of the romance through grimly realist details of living rough in the Highlands, a surprising number of writers insisted that far from being an indication of political disaffection, sympathy for Charles Edward Stuart was a measure of the virtuous sensibilities of Britons of all parties. As the author of The Wanderer explains, even though he is "well known to be a zealous Friend to the present happy Establishment [... ] I both admired and pitied the unfortunate Youth, and [after Culloden] wished him safe on the Continent."18 Likewise, a writer using the pseudonym Philalethes insisted in his 1750 Plain, Authentick and Faithful Narrative of the Several Passages of the Young Chevalier that the "candour, which can feel for a foe, and distinguish a man from a cause" will inevitably spark sympathetic interest in the prince's plight. ${ }^{19}$ Finally, from a 1749 pamphlet that proclaims itself $A$ Genuine and True Journal of the prince's escape:

17. Some Account of the Melancholy Situation of the Young Pretender in Scotland, 22. This is very close to the argument that Wilputte makes about the Haywood pamphlet; my contention here, which moves in a different direction from Wilputte's, is that Haywood was not that unusual in her rhetorical treatment of this subject.

18. The Wanderer, 3 .

19. "Philalethes," A Plain, Authentick and Faithful Narrative of the Several Passages of the Young Chevalier (London: W. Webb, 1750), 47. 
Virtue ought certainly to be revered where-ever it is found; and, with how much Reason soever the Claim of the young Chevalier may be obnoxious, it follows not, that his good Qualities should be so too, or that we should deny our Pity for those Misfortunes to which he was born. ${ }^{20}$

Nor was this insistence upon the virtues of sympathizing with Charles across political lines unique to the author of this pamphlet, a point underscored by the fact that the words just quoted were either repeated in or lifted verbatim from another pamphlet printed the same year and supposedly written by a "Gentleman residing at Paris."2l Such echoing (or outright plagiarism) hints at both the popularity of and the demand for this sort of sympathetic retelling of Jacobite adventure, as material in one pamphlet was quickly recycled into another.

That demand is unsurprising in one respect: the uprising and its aftermath would have been among the most dramatic events in living memory, and so there was an understandable hunger for facts and details. Yet one might still be a little surprised by these allegedly Hanoverian authors' claims to outdo each other in the sympathetic humanitarianism with which they approach a defeated foe. Granted, the political allegiances of the writers might be a little more complicated and murky than they admit in their pamphlets. The Wanderer has been attributed to John Burton, and if the attribution is correct, the self-proclaimed zealous friendship for the Hanoverians is a bit of political scrambling, since Burton had in fact been arrested on suspicion of Jacobite sympathies and narrowly escaped being tried. Likewise, "Philalethes" was quite possibly Robert Forbes, who, far from being a "foe" of the Stuarts, is best known as the strongly Jacobite compiler of The Lyon in Mourning. ${ }^{22}$ Yet even if the pamphlets were in fact the work of closet Jacobites desperately scribbling away in the face of catastrophic defeat, the result is not works of sustained irony in the mode of the "Patrick Graham" letter. Unlike more straightforward propagandists,

20. A Genuine and True Journal of the Most Miraculous Escape of the Young Chevalier (London: B.A., 1749), iv. This pamphlet has been attributed to John Burton, although it attacks The Wanderer, also attributed to Burton, in its preface.

21. An Authentick Account of the Conduct of the Young Chevalier (London: Nutt, Dodd, and Barnes, 1749), 15 .

22. The New Cambridge Bibliography of English Literature, ed. George Watson (Cambridge: CUP, 1971), 2: 2075. 
the "Hanoverian" authors of these romanticized versions of Culloden and its aftermath are not using irony to make a subtle case for Stuart rule. Instead, they are arguing that sympathy for the Stuarts is not just fully compatible with being a loyal Briton, but actually reflects an important aspect of the British character. The result, deliberate or not, is that Hanoverian and Jacobite political differences are submerged in a unifying and virtuous sentimental absorption in heroic, if tragic, romance.

Romance narratives are not, of course, inherently incompatible with overt political partisanship. On the contrary: writers after Culloden could look back to an established British literary tradition of recasting civil war as stylized romance. Nearly a century before, Percy Herbert had retold some of the main events leading up to the English Revolution in this manner in his Princess Cloria (1653-61), an allegorical narrative brimming with gently melancholy errant royals wandering pensively through stylized pastoral landscapes and busily swelling fountains with their tears. Yet even if The Princess Cloria is in some respects an obvious forerunner to the more romantic Jacobite pamphlets, it remains very different from them in a number of ways. For one thing, as Victoria Kahn has argued, Herbert's version of the political romance is one in which there is a very sophisticated and self-conscious attempt to represent "political crisis" by highlighting the mismatch of his genre and his subject. ${ }^{23}$ It would be difficult to make a case for that degree of literary sophistication in many of the postCulloden narratives of romantic adventure. In the 1746 romance Alexis; or the Young Adventurer, for example, the tonal shifts in the pamphlet's account of the attempts of Alexis, "a Shepherd of the first Rank" to rescue the "Swains" of Felicia from their usurping government ${ }^{24}$ do highlight the inadequacy of romance as a vehicle for the author's politics. Yet moving from celebrations of the pastoral virtues of the "gentle Alexis" to descriptions of the aftermath of Culloden (in which, we are

23. Victoria Kahn, "Reinventing Romance, or the Surprising Effects of Sympathy," Renaissance Quarterly 55.2 (2002), 630.

24. Alexis; or the Young Adventurer. A Novel (Edinburgh: A. Scott, 1746), 3. A key helpfully identifies some of the characters "disguised" under pastoral names Corydon and Tityrus are Charles' Irish companions Sullivan and O'Neil, for example - but Alexis himself is glossed only as "a brave Youth," while the Duke of Cumberland, who appears as $\mathrm{Sa}$-gui-ius is glossed as "some butchering Fellow." 
told, “[t]he pregnant Shepherdesses are ripp'd up, and the Infants drop out with the Entrails!") results in little more than a singularly jarring sense of the stark failure of the pastoral idiom in this context. ${ }^{25}$

Alexis is a minor and particularly weak pamphlet, but other Jacobite romances also feature striking, if less extreme tonal shifts. In at least some of them, however, one can also see ways in which the writer is attempting to create a narrative of heroic Jacobite virtue that draws on the appeal of romance without moving entirely away from realist narrative. The difference between such pamphlets and earlier works of sophisticated political romance, such as The Princess Cloria, is that in anchoring themselves in realist details, writers of post-Culloden pamphlets quietly shift attention from more lofty or abstract questions about the source of monarchical authority and onto the social and cultural values of the governed. If the focus in the pamphlets discussed so far has been on the virtues - plausible or not - of Charles Stuart, many others were at least as concerned with the virtues of his followers, something that complicates their political ideologies.

This is the case with Ascanius, which, as the title implies, looks back to epic and heroic adventure in its narrative style (although the author of The Wanderer insists that Griffiths gets matters comically backwards in naming his hero for Aeneas' relatively passive son). Perhaps rather more to the point here, The Wanderer also complains, quite correctly, that Ascanius doesn't sustain a mood of heroic romance. That failure is somewhat different from the superficially similar problems found in Alexis, however. For one thing, a great part of the charm of Ascanius lies in its interest in the unromantic details of the prince's flight, ranging from his unappetizing diet of oatmeal to the broad Scots cynicism of suspicious boatsmen bribed and wheedled into his service. Even so, Charles/Ascanius himself is, in most respects, a figure straight out of romance. When, for example, he learns of the illness of an attendant, he responds with a burst of formal sentimental rhetoric that, we are told, leaves all his audience in tears of admiration and sympathy:

You must not, said Ascanius, you shall not, my dear Sullivan, die and leave me in these wretched Circumstances; forbid it, gracious Heaven! let me not lose the best and most beloved Friend I have in the World!

25. Alexis; or the Young Adventurer, 4. 
- Or, if you needs will go, stay, Oh! stay a little, and take me with you; I will not, I cannot live a Day after you. To what Purpose shall I conduct myself in this strange and barbarous Part of the World; how avoid falling a Prey to my merciless Enemies. Or, if I do escape, yet Life will have no Charms for me without my Sullivan. ${ }^{26}$

Yet on completing this speech, he shifts into a rather more practical mode, going out and shooting a seabird to make Sullivan some broth. The mood then shifts again when Flora MacDonald informs Ascanius about the ruin of many of his followers: he responds with another sentimental speech and an uncontrollable "Flood of Tears," which moves his admiring audience to yet more tears of their own. ${ }^{27}$ What this pamphlet offers, in other words, is neither the superman of the Goring pamphlets nor the ineptly devious would-be tyrant of the Graham letter, but rather a prototypical Man of Feeling, who inspires the rough peasants around him not by his political rhetoric, but rather through the power of his own performative sentiment.

While the author of The Wanderer objected vehemently to this tear-soaked version of the Jacobites - presenting Charles as anything less than thoroughly soldierly, he protests, could be read as a subtle mode of undercutting the valour of the Hanoverian troops who defeated him - The Wanderer itself, like a number of other pamphlets of the day, joins Ascanius in presenting Charles as both the subject and, even more importantly, the object of powerfully sympathetic emotion. In the process, readers' attention is redirected from assessments of Charles' fitness to rule to an assertion of the value and pleasure of empathy. "The candour which can feel for a foe" becomes such an important mark of enlightened, modern British virtue that these pamphleteers come very close to suggesting that the mark of a good Hanoverian subject is in fact an ability to sympathize with the plight of Charles Stuart. Indeed, according to an anecdote that Sir Walter Scott related in The Quarterly Review, such sympathies were a measure of the moral fitness of the ruling family itself:

When the Princess of Wales [...] mentioned, with some appearance of censure, the conduct of Lady Margaret MacDonald of Sleat, who

26. Ralph Griffiths [?], Ascanius: or, The Young Adventurer; a True History (London: T. Johnston, 1746), 35-36.

27. Ralph Griffiths [?], 53. 
harboured and concealed the Prince when, in the extremity of peril, he threw himself on her protection - 'And would not you, madam,' answered Prince Frederick, "have done the same, in the like circumstances? - I hope - I am sure you would. ${ }^{28}$

Whether or not one chooses to believe that the Prince of Wales would indeed have expected his wife to hide Charles Stuart from her brotherin-law in the unlikely event of his happening to seek refuge in Kensington Palace, this story suggests both the ease with which sympathetic interest in the prince's plight could be shifted from the realm of politics to that of moral sentiment and the degree to which sentimental Jacobitism was integrated into ideas of proper, modern Britishness, rather than remaining a subversive, secretive and backward-looking ideology.

Just to be clear, the argument of this paper is not that Jacobitism was no longer seen as a threat by the late 1740 os or early 1750 s or that all writers accepted this sentimentalized version of it. Henry Fielding alone would be an impossible stumbling block for anyone attempting to make that argument, and it is probably significant that it was Scott, two or three generations after the fact, who first published the anecdote about the Princess of Wales. Yet the sympathetic portrayal of both Charles and his Highland supporters in so many of these early pamphlets adds to our understanding of the literary and cultural transformation of Jacobitism in the British imagination in the second half of the eighteenth century. The literary distance between Ascanius' appreciatively sobbing chorus of Highland attendants and James Macpherson's gloomy, doomed warrior poets is not that great, and while Fingalians aren't Jacobites, these pamphlets make clear the imaginative links between these two otherwise very different representations, for a wide British readership, of mid-century Highland culture. What turning back to these minor and mainly anonymous pamphleteers helps us see is the degree to which sentimental Jacobitism could be, long before Scott or his later Victorian admirers, at least as much a matter of cultural fashion as of political disaffection.

28. [Sir Walter Scott], "Review of The Culloden Papers," The Quarterly Review $14.28(1827), 330$. 